\title{
TMPRSS2/ETV1 Fusion Gene
}

National Cancer Institute

\section{Source}

National Cancer Institute. TMPRSS2/ETV1 Fusion Gene. NCI Thesaurus. Code C99517.

A fusion gene that results from a chromosomal translocation $t(7 ; 21)(\mathrm{p} 21 ; \mathrm{q} 22)$ which fuses the 5 ' end of the TMPRSS2 gene with exon 4 of the ETV1 gene. This rearrangement is associated with prostate carcinoma and androgen-dependent expression of this fusion gene results in overexpression of ETS translocation variant 1 protein activity. 